\title{
Arsenic and selenium in lung, liver, and kidney tissue from dead smelter workers
}

\author{
P O WESTER, ${ }^{1}$ D BRUNE, ${ }^{2}$ AND G NORDBERG ${ }^{3}$ \\ From the Departments of Medicine ${ }^{1}$ and Hygiene, ${ }^{3}$ Umeå University, Umeå, Sweden and Scandinavian \\ Institute of Dental Materials, Oslo, Norway
}

ABSTRACT Concentrations of arsenic and selenium in lung, liver, and kidney tissue from dead smelter workers and from a control group have been determined with the aid of neutron activation analysis. A sevenfold increase of arsenic was found in lung tissue from the exposed workers compared with the control group. The median value of arsenic in lung tissue from workers dead from respiratory cancer was not higher than corresponding values from workers dead from other malignancies or from cardiovascular or other diseases. With increasing period of retirement the arsenic content diminished in liver tissue but not in lung tissue, indicating a long biological half life of arsenic in lung tissue. The workers dead from malignancies had a higher As/Se quotient than workers dead from other diseases, which does not contradict the protective theory of selenium. Accumulation of antimony, cadmium, lead, and lanthanum was observed in lung tissue from the exposed workers. Six of the workers died from lung cancer and the highest concentrations of any of the elements were always observed in the lung tissue from these six cases. This observation speaks in favour of a multifactorial cause behind the excess mortality from lung cancer in smelter workers.

Arsenic has been widely discussed in connection with carcinogenesis. There have been several reports of the acute and chronic toxic effects after occupational exposure to arsenic. ${ }^{2}$ An excess of cancer mortality, especially respiratory cancer, has been reported in workers engaged in producing insecticides containing arsenic, ${ }^{3}{ }^{4}$ in workers spraying insecticides containing arsenic, ${ }^{56}$ and also in smelter workers exposed to high concentrations of inorganic arsenic. ${ }^{7-11}$ Data from animal studies have shown an interaction between arsenic and selenium compounds which may lower the toxicity of arsenic compounds. ${ }^{12-14}$ A fivefold increased lung cancer mortality has been reported in workers at Rönnskärsverken, a Swedish copper smelter, and this excess mortality showed a dose-response relationship with exposure to arsenic. ${ }^{15}$ The aim of the present study was to investigate the amounts of arsenic and selenium in lung, liver, and kidney tissue from dead workers at Rönnskärsverken, to compare these values with corresponding values from corpses from a control area, and to relate the values obtained to the causes of death.

Received 28 May 1980

Accepted 9 July 1980

\section{Material and methods}

The material consisted of 40 dead men who had worked at Rönnskärsverken, a smelter and refinery in northern Sweden, and 11 age-matched dead men from a rural control area $50 \mathrm{~km}$ away from the factory. The mean age of the workers was 66.6 years and that of the control cases 67.4 years. All workers consecutively undergoing routine necropsies at the local hospital during 1977 and 1978 were included in the study. No selection was made on the basis of diagnosis. An inspection of the necropsy protocols showed that 15 of the 40 workers $(37.5 \%)$ had died from different malignancies, six of them from respiratory cancer $(16 \%)$; none of the control cases had died from malignant disease. Seventeen of the workers $(42.5 \%)$ died from cardiovascular disease and five from cerebrovascular disease compared with seven $(64 \%)$ and three controls respectively.

The period of exposure did not differ between workers dead from malignancies (mean 31 years) or other diseases (mean 32 years). Information about smoking habits and history of employment was gathered from questionnaires answered by relatives. The company gave information about occupations at the factory. 


\section{Sample preparation}

In the dissection of tissues and preparation of samples only thoroughly cleaned glass instruments were used. Specimens of about $2 \mathrm{~g}$ wet weight were dissected with quartz knives from the right liver lobe and $1 \mathrm{~cm}$ below the diaphragmatic surface and the same amount of kidney cortex was taken from the right upper pole. The samples were transferred to cleaned quartz ampoules and freeze-dried. Specimens of about $10 \mathrm{~g}$ of wet lung tissue were dissected from the lower part of the right upper lobe. The lung samples were deep frozen and ground to powder with a quartz pestle in a quartz mortar and about $2 \mathrm{~g}$ of the powder was transferred to quartz ampoules and freeze-dried. The ampoules were sealed by flame and were then ready for irradiation.

Most of the specimens were irradiated with a thermal neutron flux of $2 \cdot 10^{3} \mathrm{n} / \mathrm{cm}^{2} \mathrm{sec}$ for three days in the $\mathrm{R} 2$ reactor at Studsvik. Chemical separation was performed with an automated ionexchange technique, and gamma-spectrometric measurements were carried out on the separated fractions as described earlier. ${ }^{16}$

\section{Statistical methods}

Assuming skew distributions of trace elements in tissues, Wilcoxon's test was used and median values are presented. For selenium the mean $\pm \mathrm{SD}$ is also given. In the statistical calculations of age, period of retirement, and time of exposure Student's $t$-test was used.

\section{Results}

The content of arsenic and selenium was determined in lung tissue from 40 dead smelter and refinery workers and nine control cases. In 21 of the workers and eight of the control cases arsenic and selenium were also determined in the liver and kidney cortex.

The 40 workers were divided into three groups according to the main diagnosis in the necropsy protocol. Group 1 contained 15 workers dead from malignancies, group 217 workers dead from cardiovascular disease, and group 3 eight workers dead from other causes.

The results are presented in tables 1-4. Table 1 presents the amounts of arsenic and selenium in lung, liver, and kidney tissue from 15 workers dead from malignancies, table 2 the corresponding values from 17 workers dead from cardiovascular disease, and table 3 those from eight workers dead from other causes. Table 4 shows the values from the control cases. Age, diagnosis, smoking habit, duration of exposure, and period of retirement from work are also presented in the tables.

The median value of As in lung tissue from all workers was $50 \mathrm{ppb}$, which is seven times that of the control cases $(p<0.001)$. The workers in group 1 had as median value in lung tissue of $54 \mathrm{ppb}$, the workers in group $244 \mathrm{ppb}$, and the workers in group $349 \mathrm{ppb}$. All these three values were significantly $(\mathrm{p}<0.001)$ higher than that in the control group, but they did not differ significantly from each other. The median value of arsenic in liver tissue from the workers, $7 \mathrm{ppb}$, did not differ significantly from the value of $4 \mathrm{ppb}$ of the control group. Workers dead

Table 1 Exposed workers with malignancies

\begin{tabular}{|c|c|c|c|c|c|c|c|c|c|c|}
\hline \multirow{2}{*}{$\begin{array}{l}\text { Age } \\
(y r)\end{array}$} & \multirow[t]{2}{*}{ Diagnosis } & \multirow[t]{2}{*}{ Smoking habits } & \multirow{2}{*}{$\begin{array}{l}\text { Period in } \\
\text { retirement } \\
(y r)\end{array}$} & \multirow{2}{*}{$\begin{array}{l}\text { Duration of } \\
\text { exposure } \\
(y r)\end{array}$} & \multicolumn{2}{|c|}{ Lung } & \multicolumn{2}{|c|}{ Liver } & \multicolumn{2}{|c|}{ Kidney } \\
\hline & & & & & As & $\mathrm{Se}$ & $A s$ & $\mathrm{Se}$ & As & $\mathrm{Se}$ \\
\hline 71 & Lung cancer & Cigarette smoker & 5 & 41 & 93 & 126 & 7 & 150 & 20 & 420 \\
\hline 71 & Lung cancer & Non-smoker & $6 \cdot 5$ & 37 & 48 & 132 & 9 & 190 & 12 & 240 \\
\hline 67 & Lung cancer & Cigarette smoker & 23 & 22 & 29 & 243 & - & & & \\
\hline 65 & Lung cancer & Pipe smoker & 1 & 34 & 40 & 68 & 6 & 250 & 11 & 320 \\
\hline 72 & Lung cancer & Ex-smoker (pipe) & 8 & 27 & 205 & 201 & 7 & 261 & 2 & 570 \\
\hline 62 & Lung cancer & Ex-smoker (pipe) & 1 & 34 & 130 & 150 & 3 & & 2 & \\
\hline 58 & Pancreas cancer & & 19 & 16 & 30 & 123 & 4 & 200 & 3 & 250 \\
\hline 70 & Pancreas cancer & & 5 & 38 & 51 & 75 & 2 & 150 & 2 & 310 \\
\hline 73 & Colon cancer & Non-smoker & 8 & 39 & 60 & 158 & - & & - & \\
\hline 82 & Colon cancer & $\begin{array}{c}\text { Ex-smoker (cigarette } \\
+ \text { pipe) }\end{array}$ & 17 & 27 & 46 & 127 & 一 & & - & \\
\hline 84 & Rectal cancer & Ex-smoker (cigarette) & 19 & 27 & 56 & 115 & - & & - & \\
\hline 57 & $\begin{array}{l}\text { Cancer of the } \\
\text { urinary bladder }\end{array}$ & Pipe smoker & 0 & 24 & 41 & 160 & 15 & 350 & 2 & 490 \\
\hline 61 & Liver cancer & Non-smoker & 1 & 31 & 78 & 430 & 15 & 140 & 16 & 2120 \\
\hline 76 & $\begin{array}{l}\text { Chronic lymphatic } \\
\text { leukaemia }\end{array}$ & Non-smoker & 9 & 37 & 102 & 109 & 30 & 200 & 20 & 330 \\
\hline 60 & Myelomatosis & Pipe smoker & 1 & 30 & 49 & 203 & - & & - & \\
\hline $68 \cdot 6$ & $\begin{array}{l}\text { Median values } \\
\text { Mean values }\end{array}$ & & $8 \cdot 2 \pm 7 \cdot 7$ & $30 \cdot 9 \pm 7 \cdot 1$ & 54 & $\begin{array}{l}132 \\
159 \pm 89\end{array}$ & 7 & $\begin{array}{l}195 \\
210 \pm 68\end{array}$ & 5 & $\begin{array}{l}330 \\
561 \pm 594\end{array}$ \\
\hline
\end{tabular}


Table 2 Exposed workers with cardiovascular disease

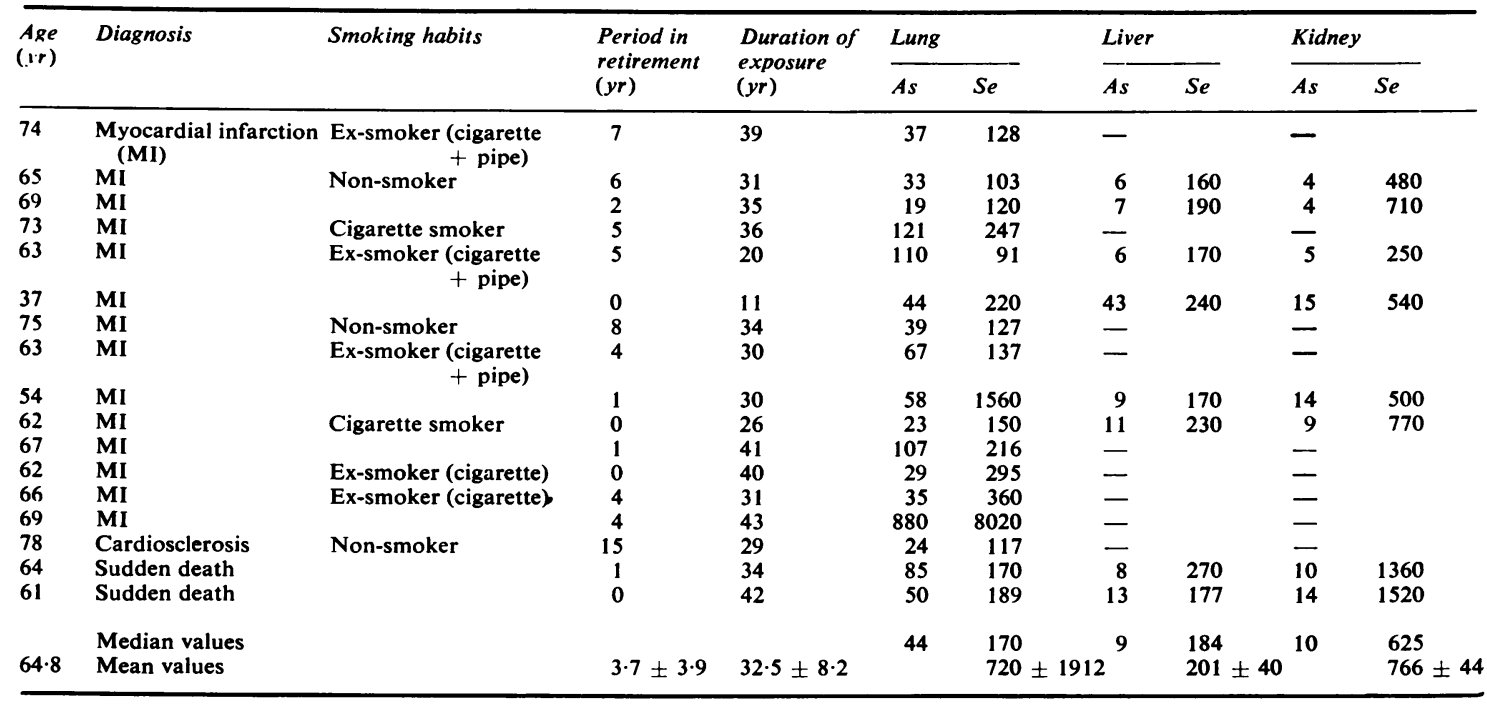

from malignancies had about the same median As-value in liver tissue as the workers dead from cardiovascular disease. The median values for As in kidney cortex from the control cases, $5 \mathrm{ppb}$, was the same as that from all workers and did not differ significantly from the median values in the subgroups of workers.

The median Se-value in lung tissue in the control group, $120 \mathrm{ppb}$, did not differ from the corresponding value in all workers, $145 \mathrm{ppb}$. The workers in group 1 showed a somewhat lower median value, $132 \mathrm{ppb}$, than those in group 2, though not significantly so. This tendency for a low Se-value in workers dead from malignancies complies with a $5 \%$ significance for the values in kidney cortex, $330 \mathrm{ppm}$ v $755 \mathrm{ppm}$ in control cases. In liver tissue there were no significant differences in Se content between controls and workers or between different groups of workers.

\section{Discussion}

A wide range of As-values in normal lung, liver, and kidney tissue has been reported. ${ }^{17}$ One reason for this may be due to problems of contamination during sample preparation or during the analytical procedure. In the present work great care was taken to avoid contamination during preparation of the samples, and with the neutron activation technique used there is no contamination during the analytical procedure.

Another reason for the wide range of normal values presented may be that $A s$, as a volatile element, is lost during the preparation of samples or in the analytical process. The drying step in the preparation of samples and the analytical technique ${ }^{18}$ used in the present study has been tested earlier and found to be satisfactory.

Table 3 Exposed workers with other diagnoses

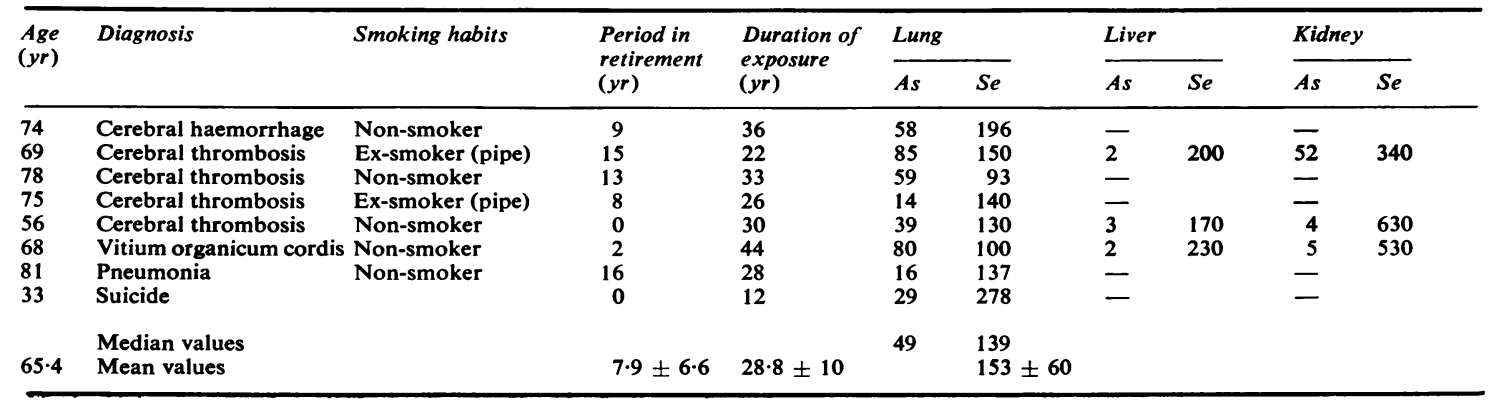


Table 4 Control cases

\begin{tabular}{|c|c|c|c|c|c|c|c|c|}
\hline \multirow{2}{*}{$\begin{array}{l}\text { Age } \\
(y r)\end{array}$} & \multirow[t]{2}{*}{ Diagnosis } & \multirow[t]{2}{*}{ Smoking habits } & \multicolumn{2}{|c|}{ Lung } & \multicolumn{2}{|c|}{ Liver } & \multicolumn{2}{|c|}{ Kidney } \\
\hline & & & As & Se & As & $\mathrm{Se}$ & $A s$ & Se \\
\hline 68 & $\begin{array}{l}\text { Myocardial infarction } \\
\text { (MI) }\end{array}$ & Non-smoker & 13 & 122 & 13 & 200 & 10 & 700 \\
\hline 69 & MI & Non-smoker & 18 & 110 & 9 & 450 & 5 & 1030 \\
\hline 68 & MI & Non-smoker & 10 & 93 & 8 & 190 & 4 & 1030 \\
\hline 42 & MI & & 5 & 120 & 2 & 230 & 7 & 670 \\
\hline 76 & MI & & 1 & 92 & & & & \\
\hline 70 & MI & Cigarette smoker & 7 & 220 & - & & - & \\
\hline 75 & $\begin{array}{l}\text { Status post, } \mathrm{MI}+ \\
\text { pulmonary embolus }\end{array}$ & Non-smoker & 11 & 103 & 3 & 190 & 4 & 600 \\
\hline 76 & Cerebral haemorrhage & Non-smoker & 1 & 44 & 3 & 460 & 2 & 830 \\
\hline 66 & Cerebral haemorrhage & Non-smoker & 1 & 91 & & & & \\
\hline 60 & Cerebral thrombosis & Non-smoker & 6 & 120 & 1 & 140 & 14 & 370 \\
\hline 72 & Vitium organicum cordis & Non-smoker & 9 & 700 & 4 & 150 & 3 & 810 \\
\hline $67 \cdot 4$ & $\begin{array}{l}\text { Median values } \\
\text { Mean values }\end{array}$ & & 7 & $\begin{array}{l}120 \\
165 \pm 182\end{array}$ & 4 & $\begin{array}{l}195 \\
245 \pm 122\end{array}$ & 5 & $\begin{array}{l}755 \\
755 \pm 207\end{array}$ \\
\hline
\end{tabular}

Several investigators of trace elements in biological material have observed that most elements are not normally distributed, and the use of the median as a central value has been regarded as more accurate than the mean. ${ }^{19-21}$ Consequently, median values are given and Wilcoxon's test has been applied in the present study. In a previous study of trace elements in normal human heart tissue, however, a few elements, among them selenium, appeared to have a normal distribution. ${ }^{22}$ Thus for selenium in the present study the mean $\pm S D$ values are given as well.

The As-values in our control group agree with those presented by Lyengar $e t a^{17}$ and Lievens $e t$ $a l^{23}$ for normal lung, liver, and kidney tissue. No significant differences in As-content are noted between lung, liver, or kidney tissue. Our Se-values in the control group agree well with reported normal values. In the present study as well as others $^{172425}$ there is more $\mathrm{Se}$ in the kidneys and less in the lungs.

In several epidemiological studies of workers exposed to arsenic an excess mortality from malignancies is reported, especially respiratory cancer. ${ }^{3-11}$ Axelson et $a l^{15}$ reported from Rönnskärsverken, the smelter from which the present investigation is made, a fivefold increased lung cancer mortality and a twofold increased cardiovascular mortality, showing a dose-response relationship to arsenic exposure.

In the present study a high proportion of the workers died from malignancies, especially lung cancer. Fifteen per cent of the workers had respiratory cancer compared to $12 \%$ in the material of Axelson et al. A slight increase of malignant blood diseases is reported by Axelson et $a^{15}$ and also by Ott et al. ${ }^{4}$ In the present study there are two cases of malignant blood diseases.
The content of arsenic in lung tissue from exposed workers shows a sevenfold increase compared with control cases in the present study. This increase could be taken as a support for As as a causative factor for the increased mortality in respiratory cancer in workers exposed to arsenic. There is not, however, more As in the lungs of the workers dead from respiratory cancer than in the lungs from workers dead from other malignancies, from cardiovascular or other diseases. On the other hand, this does not mean that As is without importance in carcinogenesis. It is necessary to consider many factors such as the amount and duration of exposure to As, biological half life in various tissues, time required to develop malignancy, concomitant exposure to other agents, smoking habits, and protecting factors. The duration of exposure was about the same among workers in group 1 and group 2, 31 and 33 years respectively. The duration of exposure in the present study is equal to the duration of employment, but this is not a good index of true exposure since working conditions in the factory are complex and have also changed much during the past 40 years.

There was a significant difference in the period of retirement from work between workers dead from cardiovascular disease (group 1) on the one hand and workers dead from malignancies (group 2) and other diagnoses (group 3 ), viz 3.7 years against 8.2 and 7.9 respectively. The short period of retirement from work in group 1 may imply that malignancies have not had the same possibility to develop as in the other groups.

The measured content of an element in tissues of exposed individuals depends among other things on the biological half life of the element in the particular tissue. The period between the last exposure and death varied in the present investigation between 0 
and 23 years. In lung tissue there was no tendency for the As-values to diminish when the period of elapse increased, which indicates a long biological half life. In liver tissue, however, the biological half life seems to be much shorter. There were significantly higher As-values in workers when the period of retirement from work was 0 year (median $13 \mathrm{ppb})$ or $0-1$ year (10 ppb) as compared to those with more than one year (median $6 \mathrm{ppb}$ ) of retirement $(p<0.05)$. The long biological half life for As in lung tissue indicates that As might be specially dangerous for this tissue.

Smoking is a well-known risk factor for developing respiratory cancer. There was a high proportion of smokers and ex-smokers among the workers (seven smokers, 11 ex-smokers, 12 non-smokers). Unfortunately, information about smoking habits is missing for 10 workers. Among the control cases there was only one cigarette smoker. The As median values in lung tissue for the workers did not differ among smokers (41 ppb), ex-smokers (56 ppb), and non-smokers (53 ppb). Among the six cases with respiratory cancer there were two cigarette smokers, one pipe smoker, two ex-pipe smokers, and only one non-smoker. Thus smoking may well have contributed to factors of importance for the development of respiratory cancer in the present study.

Selenium has been reported to have a protective effect against some toxic effects of arsenic in animal experiments, ${ }^{12-14}$ and similar interactions may be important in relation to lung cancer. The mean $\mathrm{As} / \mathrm{Se}$ quotient in lung tissue in the control cases in the present material was $0.06 \pm 0.05$, which was significantly lower than for the workers. The workers with malignancies had a mean As/Se quotient of $0.61 \pm 0.42$, which was higher than that $(0.34 \pm 0.26)$ from the workers dead from other diseases $(p<0.05)$. The value for the workers dead from respiratory cancer, however, was the same $(0.61 \pm 0.30)$ as for the workers dead from other malignancies. Thus to judge from our results it is not unlikely that selenium may have some kind of protective effect. No definite conclusions can be drawn from the present study.

In addition to arsenic and selenium other elements or chemical compounds, such as sulphur dioxide, lead, cadmium, antimony and lanthanum, may become volatilised and appear as airborne dust or gases.

We have no information about sulphur dioxide in the present material. Antimony, cadmium, lead, and lanthanum, and some other elements were found to have accumulated in the lung tissue of the workers. ${ }^{26} 27$ Antimony was determined in all cases and the other elements in 21 of the workers.
Remarkably, the highest levels of any of these elements in lung tissue were always observed among the six cases with respiratory cancer. Thus the highest concentrations of antimony in lung tissue were observed in nos 1 and 5 among the cases with respiratory cancer, of cadmium in case no 3 , of lead in case no 4, and of lanthanum in case no 6. The highest concentrations of arsenic were also observed in two of the cases with lung cancer (nos 5 and 6) if one worker with a short period of retirement employed at the As-refinery is excluded. In conclusion it is impossible to point out one particular factor or toxic element as the causative factor for the development of respiratory cancer. A multifactorial theory seems very likely. It may well be that different factors added together, such as smoking, exposure to toxic gases or metals, or both, etc produce the deleterious result. The retention of different toxic metals in the tissues during a sufficiently long period may well be of crucial importance for the development of cancer. Thus further multi-element studies in tissues, especially of toxic elements retained in tissues, are much needed.

Financial support was given by Workhealthfund.

\section{References}

${ }^{3}$ Holmqvist J. Occupational arsenical dermatitis. A study among employers at a copper smelting works including investigations of skin reactions to contact with arsenic compounds. Acta Dermatologica et Venereologica 1951;31,suppl 26:1-214.

2 Nordberg GF, Pershagen G, Lauwerys R. Inorganic arsenic-toxicological and epidemiological aspects. Odense, Denmark: Odense University Printing Office, 1979:1-113. (Report to the Commission of European Communities).

${ }^{3}$ Hill AB, Faning EL. Studies in the incidence of cancer in a factory handling inorganic compounds of arsenic. I Mortality experience in the factory. Br J Ind Med 1948;5:1-6.

4 Ott MG, Holder BB, Gordon HL. Respiratory cancer and occupational exposure to arsenicals. Arch Environ Health 1974;29:250-5.

5 Roth F. Ueber den Bronchialkrebs arsengeschädigter Winzer. Virchows Arch 1958;331:119-37.

- Galy P, Touraine R, Brune J, Roudier P, Gallois P. Le cancer pulmonaire d'origine arsénicale des vignerons du Beaujolais. Journal Francais de Medicine et Chirurgie Thoraciques 1963;17:303-11.

? Lee AM, Fraumeni JF Jr. Arsenic and respiratory cancer in man: an occupational study. J Natl Cancer Inst 1969;42:1045-52.

8 Tokudome S, Kuratsune M. A cohort study on mortality from cancer and other causes among workers at a metal refinery. Int J Cancer 1976;17:310-7.

9 Pinto SS, Enterline PE, Henderson V, Varner MO. Mortality experience in relation to a measured arsenic trioxide exposure. Environ Health Perspect 1977;19: 127-30. 
${ }^{10}$ Rencher AC, Carter MW, McKee DW. Mortality at a large western copper smelter. JOM 1977;19:754-8.

11 Pershagen G, Elinder C-G, Bolander A-M. Mortality in a region surrounding an arsenic emitting plant. Environ Health Perspect 1977;19:133-7.

${ }^{12}$ Hill $\mathrm{CH}$, Matrone G. Chemical parameters in the study of in-vivo and in-vitro interactions of transition elements. Fed Proc 1970;29:1474-9.

${ }^{13}$ Schrauzer GN, White DA, McGinness JE, Scheider CJ, Bell LJ. Arsenic and cancer: Effects of joint administration of arsenite and selenite on the genesis of mammary adenocarcinoma in inbred female C $3 \mathrm{H} / \mathrm{S} \mathrm{T}$ mice. Bioinorg Chem 1978;9:245-53.

14 Task Group on Metal Interaction. Factors influencing metabolism and toxicity of metals. Environ Health Perspect 1978;25:3-41.

15 Axelson O, Dahlgren E, Jansson C-D, Rehnland SO. Arsenic exposure and mortality: a case-referent study from a Swedish copper smelter. Br J Ind Med 1978;35: 8-15.

16 Samsahl K, Wester PO, Landström O. An automatic group separation system for the simultaneous determination of a great number of elements in biological material. Anal Chem 1968;40:181-7.

${ }^{17}$ Lyengar GV, Kollmer WE, Bowen HJM. The elemental composition of human tissues and body fluids. Weinham, New York: Verlag Chemie, 1978.

18 Wester PO, Brune D, Samsahl K. Radiochemical recovery studies of a separation scheme for 23 elements in biological material. Int J Appl Radiat Isot 1964;15:59-67.
${ }^{16}$ Harding-Barlow J. Studies on the trace element content of human tissues. Capetown: University of Capetown, 1961:1-202. (Ph D dissertation.)

${ }^{20}$ Perry HM Jr, Tipton JH, Schroeder HA, Cook MJ. Variability in the metal content of human organs. $J$ Lab Clin Med 1962;60:245-53.

21 Wester PO. Trace elements in heart tissue. Acta Med Scand 1965b;suppl 439:1-48.

22 Wester PO. Concentration of 24 trace elements in human heart tissue determined by neutron activation analysis. Scand J Clin Lab Invest 1965a;17:357-70.

${ }^{23}$ Lievens P, Versieck J, Cornelis R, Hoste J. The distribution of trace elements in normal human liver determined by semi-automated radiochemical neutron activation analysis. J Radioanalytical Chemistry 1977;37:483-96.

${ }^{24}$ Bowen HJM. Trace elements in biochemistry. London and New York: Academic Press, 1966.

${ }^{25}$ Hamilton EI, Minski MJ, Cleary JJ. The concentration and distribution of some stable elements in healthy human tissues from the United Kingdom. Sci Total Environ 1972:1:341-74.

${ }^{26}$ Nordberg G, Wester PO, Brune D. Tissue levels of 25 elements in smelter workers. Proceedings of International symposium on the control of air pollution in the working environment. Stockholm: Liber tryck, 1978:261-72.

${ }^{27}$ Brune D, Nordberg G, Wester PO. Distribution of 23 elements in kidney, liver, and lung of a control group in north Sweden and of exposed workers from a smeltery and refinery. Sci Total Environ (in press). 